\title{
Cameras and carcasses: historical and current methods for using artificial food falls to study deep-water animals
}

\author{
David M. Bailey ${ }^{1,2, *}$, Nicola J. King ${ }^{1}$, Imants G. Priede ${ }^{1}$ \\ ${ }^{1}$ Oceanlab, University of Aberdeen, Newburgh, Aberdeenshire AB41 6AA, UK \\ ${ }^{2}$ Present address: University of Glasgow, Graham Kerr Building, Glasgow G12 8QQ, UK
}

\begin{abstract}
Deep-ocean animals remain poorly understood compared to their shallow-water relatives, mainly because of the great cost and difficulty involved in obtaining reliable ecological data. This is a serious issue, as exploitation of deep-water resources progresses without sufficient data being available to assess its risks and impacts. First described almost $40 \mathrm{yr}$ ago, the use of baited cameras was pioneered by deep-sea biologists and is now a widely used technique for assessing patterns of animal behavior, abundance, and biodiversity. The technique provides a non-destructive and cost-effective means of collecting data, where other techniques such as trawling are difficult or impractical. This review describes the evolution of baited camera techniques in deep-sea research from the early deployments, through recent programs to investigate trends in animal distribution with depth, latitude, and ocean basin. The techniques used for imaging, baiting, and analysis are synthesized, with special consideration of the modeling techniques used in assessing animal abundance and biomass.
\end{abstract}

KEY WORDS: Deep water - Scavengers $\cdot$ Marine technology $\cdot$ Underwater cameras $\cdot$ Literature review $\cdot$ Fisheries $\cdot$ Stock assessment $\cdot$ Environmental assessment

\section{INTRODUCTION}

Baited camera deployment is a deceptively simple technique for the study of the marine environment. Simple, because at its most basic level it requires only a time-lapse camera and bait held in its field of view, but deceptive because the view of the marine environment is small and the events seen are artificial. The great advantage of baited systems is that deployment at a single site aggregates animals from a large distance around it, allowing the animals to be identified, counted, and measured. Diverse and fascinating deepocean scavenger communities have been revealed by such cameras, and technical and scientific advances continue to improve their usefulness. The technical improvements that allow more effective deep-water research have progressed alongside similar develop- ments in the oil, gas, and fishing industries, bringing the threat of overfishing and habitat destruction to deep-water communities. With these dangers and the discovery of fragile habitats such as cold water coral reefs, effective deep-ocean survey and monitoring tools will become increasingly necessary.

The authors have used baited cameras for much of their work, collecting ecological, behavioral, and physiological data, and much of the material presented in the present study is from these projects and those of our immediate collaborators. It is the aim of this review to highlight the key historical advances in baited camera research and describe some of the discoveries made in baited camera surveys worldwide. This review will also illustrate the general advantages and disadvantages of baited cameras and then focus on different approaches to imaging, baiting, and data interpretation. 


\section{HISTORY}

Baited cameras have now been deployed worldwide, to the greatest depths of the world's oceans, but with a bias towards the United States and European ocean margins. From the first baited camera experiments, the majority of studies have been undertaken with systems mounted on free-falling autonomous vehicles (also known as landers or pop-up vehicles). These vehicles consist of a frame, on which the camera system is mounted, and a buoyancy unit. The system is ballasted, usually with steel scrap, to make it negatively buoyant. The lander is then deployed by dropping it from the crane or A-frame of a ship; it sinks to the seafloor and takes photographs or video at pre-set intervals. At the end of the experiment, the ballast is dropped by the lander, usually on receipt of an acoustic command from the surface, and the lander is brought to the surface by the buoyancy unit.

Camera and water current meter data are then retrieved from the lander, batteries are recharged or replaced, and the lander is prepared with new ballast and bait for the next deployment. The use and advantages of autonomous vehicles have been reviewed by Priede \& Bagley (2000) and Bagley et al. (2004). These authors particularly highlighted the great time and cost savings associated with the use of landers, allowing the deploying vessel to do other work while the lander is in the water (Table 1). In some applications, lander systems can be left in situ for months or even years. More recently, a number of other studies have been conducted by sinking carcasses and periodically visiting them with remotely operated vehicles (ROVs) or submersibles (Smith 1985), by manually placing camera systems and bait on the seafloor using these vehicles (Widder et al. 2005), or by baiting the ROV itself (Tamburri et al. 2000, Trenkel et al. 2004). The variety of vehicles used to deploy cameras, and the range of buoyancy, ballast, and release mechanisms is great and worthy of a review in itself (e.g. Jamieson 2004). This paper, however, concentrates on scientific payloads, analyses, and the results achieved. A selection of key lander systems and experiments are highlighted in Table 2.

First steps: Isaacs and the 'monster camera'. The first photographic lander was developed by Ewing and co-workers in the 1940s (described in Ewing et al. 1967), and was used primarily for the study of seabed features such as sand ripples. The first deep-sea baited camera was developed by Isaacs (1969) at Scripps Institution of Oceanography (University of California, San Diego). Known as the 'monster camera' (Fig. 1), this $7000 \mathrm{~m}$ rated lander system was deployed in the North Pacific at depths of up to $5835 \mathrm{~m}$ (Heezen \& Hollister 1971, Dayton \& Hessler 1972). Later surveys in the Pacific, Indian, and Southern Oceans demonstrated the widespread presence of an abundant and active scavenging fauna, with fish arriving at the bait

Table 1. Examples of the advantages and disadvantages of various gears for the assessment of animal biodiversity, abundance, and biomass in benthic deep-water systems

\begin{tabular}{|c|c|c|}
\hline Survey gear & Advantages & Disadvantages \\
\hline Baited camera & $\begin{array}{l}\text { Small sea time requirement for long } \\
\text { observation } \\
\text { Deployment and recovery possible from } \\
\text { smaller vessels, with non-specialist } \\
\text { crews and equipment } \\
\text { Provides behavioral data on scavengers } \\
\text { Relatively non-destructive }\end{array}$ & $\begin{array}{l}\text { Lack of standardization } \\
\text { Many assumptions in abundance estimates } \\
\text { Some taxa/size ranges do not come to bait } \\
\text { Animals may be difficult to identify to species from images } \\
\text { Expensive to build equipment } \\
\text { Relatively high chance of equipment loss } \\
\text { Weights of animals cannot be determined directly, and require } \\
\text { length/weight relationships from captured specimens }\end{array}$ \\
\hline Bottom trawling & $\begin{array}{l}\text { Obtains voucher specimens } \\
\text { Abundance and biomass estimates } \\
\text { relatively simple } \\
\text { Historical datasets available for } \\
\text { comparison }\end{array}$ & $\begin{array}{l}\text { Destructive } \\
\text { Time on bottom difficult to determine at depth, making } \\
\text { abundance estimates less precise } \\
\text { On rougher ground some nets fish poorly or will be damaged } \\
\text { Ship cannot do other work while fishing } \\
\text { Net avoidance varies between net types and taxa } \\
\text { Few ships and individuals have the ability to trawl to abyssal } \\
\text { depths }\end{array}$ \\
\hline $\begin{array}{l}\text { ROV/ submersible } \\
\text { survey }\end{array}$ & $\begin{array}{l}\text { Some ability to obtain voucher specimens } \\
\text { High-quality video and stills from cameras } \\
\text { available }\end{array}$ & $\begin{array}{l}\text { Ship cannot do other work while dive underway } \\
\text { Camera avoidance varies between taxa } \\
\text { Field of view and angle of line of sight vary between and } \\
\text { during surveys }\end{array}$ \\
\hline $\begin{array}{l}\text { Camera sled } \\
\text { survey }\end{array}$ & $\begin{array}{l}\text { Highly standardized results } \\
\text { Easy to tell whether camera was on the } \\
\text { bottom } \\
\text { Relatively non-destructive }\end{array}$ & $\begin{array}{l}\text { Ship cannot do other work while tow underway } \\
\text { Camera avoidance varies between taxa } \\
\text { Difficult to estimate sizes of animals which are not on the } \\
\text { bottom, unless stereo cameras are used }\end{array}$ \\
\hline
\end{tabular}


Table 2. A selection of key baited camera systems and deployments in the deep ocean. CNP: Central North Pacific

\begin{tabular}{|c|c|c|c|c|}
\hline Year & System & Location(s) & Key result & Source \\
\hline $1969-1975$ & Monster camera & $\begin{array}{l}\text { Pacific, Indian and } \\
\text { Antarctic Oceans, } \\
\text { Mediterranean }\end{array}$ & $\begin{array}{l}\text { First observations } \\
\text { Differences between ocean } \\
\text { basins described }\end{array}$ & $\begin{array}{l}\text { Isaacs (1969) } \\
\text { Heezen \& Hollister (1971) } \\
\text { Isaacs \& Schwartzlose } \\
(1975)\end{array}$ \\
\hline 1981 & $\begin{array}{l}\text { Bathysnap (baited } \\
\text { version, also known as } \\
\text { 'Bathysnack') }\end{array}$ & North Atlantic & $\begin{array}{l}\text { Establishment of latitudinal } \\
\text { patterns in scavenger } \\
\text { distribution }\end{array}$ & Thurston et al. (1995) \\
\hline 1983 & $\begin{array}{l}\text { Scripps free vehicle video } \\
\text { (FVV) }\end{array}$ & North Pacific & $\begin{array}{l}\text { Video recordings reveal } \\
\text { swimming speeds and } \\
\text { approach directions of } \\
\text { scavengers }\end{array}$ & $\begin{array}{l}\text { Wilson \& Smith (1984) } \\
\text { Laver et al. (1985) }\end{array}$ \\
\hline $1986-2006$ & $\begin{array}{l}\text { Acoustic tracking } \\
\text { experiment (ATEX) and } \\
\text { Aberdeen University } \\
\text { deep-ocean submersible } \\
\text { (AUDOS), Robust } \\
\text { biodiversity lander } \\
\text { (ROBIO) }\end{array}$ & $\begin{array}{l}\text { North Atlantic and } \\
\text { North Pacific, } \\
\text { Southern Indian } \\
\text { Ocean }\end{array}$ & $\begin{array}{l}\text { Acoustic tracking of } \\
\text { abyssal fishes provides } \\
\text { detailed information about } \\
\text { the behavior of fishes } \\
\text { Deepest fishes recorded at } \\
\text { baited lander } 5900 \mathrm{~m} \text { CNP } \\
\text { Commercial use of baited } \\
\text { camera in the deep ocean }\end{array}$ & $\begin{array}{l}\text { Bagley et al. (1994) } \\
\text { Henriques (2002) } \\
\text { Priede et al. (1990) }\end{array}$ \\
\hline 1978,1989 & $\begin{array}{l}\text { 'Autonomous instrument } \\
\text { carriers' lowered by wire }\end{array}$ & $\begin{array}{l}\text { Philippine, Chile and } \\
\text { Mariana Trenches }\end{array}$ & $\begin{array}{l}\text { Deepest baited camera } \\
\text { deployments (>10000 m) } \\
\text { observe only crustaceans } \\
\text { and not fishes }\end{array}$ & $\begin{array}{l}\text { Hessler et al. (1978) } \\
\text { Beliaev (1989) }\end{array}$ \\
\hline $\begin{array}{l}1998 \\
2001-2006\end{array}$ & $\begin{array}{l}\text { Large abyssal food fall } \\
\text { (LAFF) and Deep-ocean } \\
\text { benthic observer (DOBO) } \\
\text { landers }\end{array}$ & North Atlantic & $\begin{array}{l}\text { Marine mammal deploy- } \\
\text { ment reveals temporal } \\
\text { succession and interactions } \\
\text { between scavenging } \\
\text { species. Periodic bait } \\
\text { release system developed }\end{array}$ & $\begin{array}{l}\text { Jones et al. (1998) } \\
\text { Kemp et al. (2006) } \\
\text { Kemp et al. (2007) }\end{array}$ \\
\hline 2005 & Eye in the sea & Gulf of Mexico & $\begin{array}{l}\text { Red light illumination and } \\
\text { electronic jellyfish }\end{array}$ & Widder et al. (2005) \\
\hline
\end{tabular}

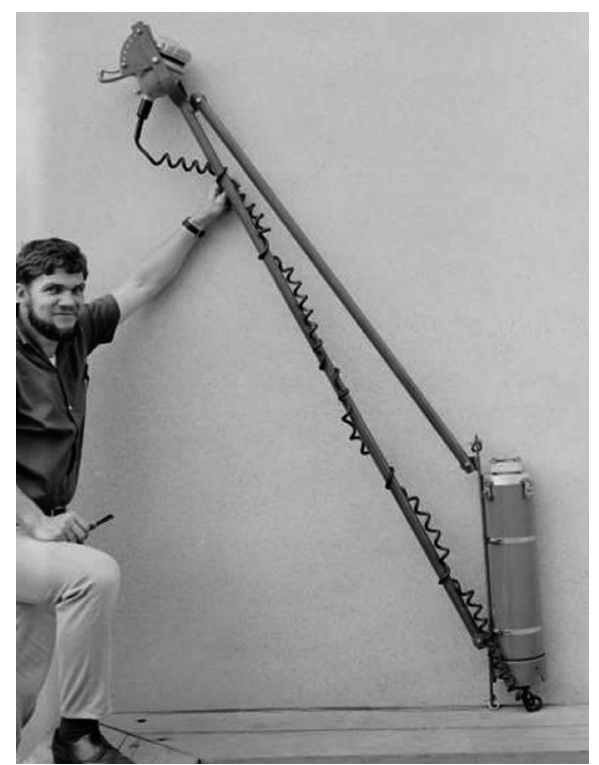

Fig. 1. The 'monster camera'. In this image the camera housing is inverted at the bottom right and the strobe is at the top left. The system was deployed with the camera facing down, towards a perforated metal can containing the bait. Photo courtesy of Scripps Institution of Oceanography Library in $<30$ min in most deployments (Isaacs \& Schwartzlose 1975). Amongst the animals observed off Baja California were a sleeper shark at 2039 m (Heezen \& Hollister 1971) and sablefish, grenadiers, and hagfish at $1400 \mathrm{~m}$ (Isaacs 1969). Isaacs (1969) suggested that some apparently Arctic species, such as sleeper sharks and sablefish, were really deep-water animals that merely 'outcrop' at high latitudes, where cold water is close to the surface. Having shown evidence that deep-sea scavengers were abundant, Isaacs \& Schwartzlose (1975) speculated that deep-ocean scavengers use odor plumes to find bait, and noted that differences in overlying productivity affected both the numbers of animals attracted and their apparent level of hunger and interest in the bait.

The observation of large numbers of active scavengers contributed to the ongoing controversy over the role of habitat complexity in supporting the observed diversity of deep-ocean species (Dayton \& Hessler 1972, Grassle \& Sanders 1973). Controversy on this matter raged for years, with various authors presenting contrary findings about the abundance and significance of carrion items as part of a habitat mosaic, and 
disagreeing over the significance of scavengers in deep-ocean habitats (reviewed in Stockton \& DeLaca 1982). Baited cameras are one of the few ways to study deep-water scavengers, as natural food falls in the deep ocean are seldom seen (Stockton \& DeLaca 1982). Wilson \& Smith (1984) made several important contributions to understanding the role of scavengers by using the free vehicle video (FVV) system to study the behavior of foraging abyssal grenadiers. Later, a modified version of this lander was used to make detailed measurements of the swimming speeds of scavenging amphipods (Wilson \& Smith 1984, Laver et al. 1985). These studies provided key insights into the foraging methods of deep-ocean scavengers and led to first detailed descriptions of proposed energetic strategies. These, and following, studies quickly showed that deep-water scavengers possessed particular energetic characteristics, primarily, low routine metabolic rates (Seibel \& Drazen 2007). Our understanding of deepwater animal energetics remains poor, and is a significant limitation to modeling their foraging behavior. As well as collecting these biological data, Wilson \& Smith (1984) also made the first explicit link between the arrival rates of animals at cameras and the numbers of those same species caught by trawls in similar locations.

The search for spatial and temporal patterns. Researchers in the UK began 2 major series of baited camera experiments, which continue to widen the spatial range covered. The main areas of investigation have been to determine how depth and overlying productivity affect community composition, and how scavenger communities differ between ocean basins.
The landers used were a baited version of the Institute for Oceanographic Sciences Bathysnap system (Lampitt \& Burnham 1983) and the acoustic tracking experiment (ATEX) (Priede \& Smith 1986). Bathysnap is a 'free-fall camera and current meter system' and differed from many of the systems that preceded it by resting directly on the seafloor, with the camera facing outwards at a downward angle. Usually deployed as an unbaited time-lapse photography system, the history of Bathysnap has been reviewed by Bett (2003). The initial baited (or Bathysnack) experiment, at $4009 \mathrm{~m}$ in the Northeast Atlantic, used the flesh of abyssal grenadiers Coryphaenoides armatus caught at the same depth. The bait was wrapped in fine cotton gauze, and attracted amphipods and fishes (but not large grenadiers) (Lampitt et al. 1983). A key finding was that changes in current direction and velocity had powerful effects on the numbers of animals seen at the bait, as Wilson \& Smith (1984) observed using the FVV in the Pacific.

The first ATEX lander consisted of the FVV fitted with an acoustic tracking module and was deployed in the North Pacific in 1985 (Priede \& Smith 1986). ATEX and the subsequent Aberdeen University deep-ocean submersible (AUDOS) and robust biodiversity (ROBIO) landers (Fig. 2) have since been deployed worldwide to depths of up to $5900 \mathrm{~m}$. Members of this family of vehicles consist of a time-lapse stills or video camera facing downwards from a frame moored $2 \mathrm{~m}$ above the seafloor, kept in tension by the lander's buoyancy (Fig. 2). The majority of ATEX and AUDOS models included an acoustic system capable of tracking ingestible transponders. These transponders were
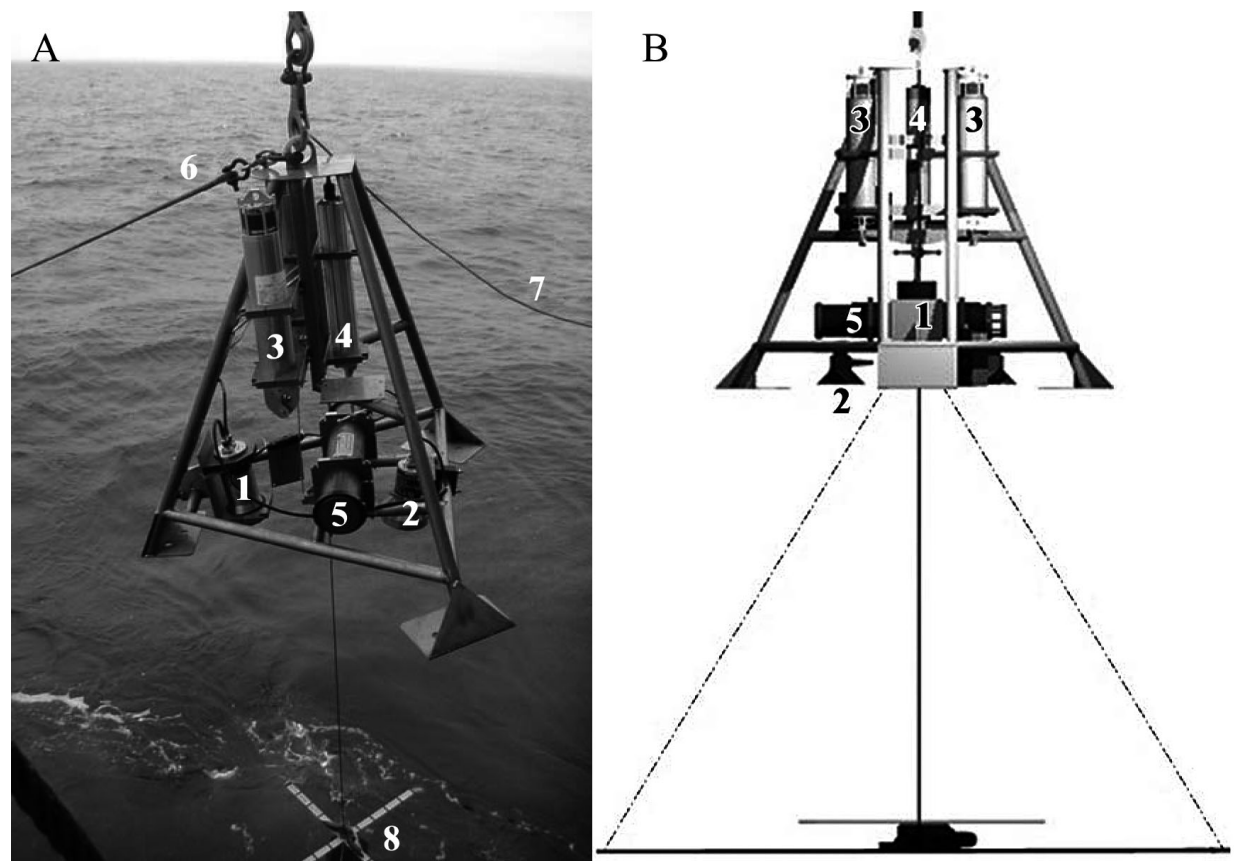

Fig. 2. The ROBIO lander, the latest version of the ATEX/AUDOS family of baited landers, being deployed in tethered mode (see Table 2 for further details): (A) ROBIO being deployed on the Mid-Atlantic Ridge, and (B) diagrammatic representation (AutoCAD) of ROBIO in tethered mode. The lander consists of a grade- 2 titanium frame with a digital camera (1), flash unit (2), acoustic releases (3), current meter (here a Sensortek current meter) (4), battery housing and rechargeable battery (5), and a $2 \mathrm{~m}$ wire stop with bait, reference cross, and ballast (8). The link with the mooring line (6) and quick release line are visible (7) in (A). The dashed lines in (B) indicate the field of view of the camera 
hidden in bait packages and, once eaten, allowed the subsequent movements of the fish to be recorded at pre-selected time intervals (usually each minute) to a range of $500 \mathrm{~m}$ (Bagley et al. 1994). Unlike previous landers, the ATEX was baited with a single fish carcass, which was open to the scavengers. As the bait was consumed, the scavengers dispersed, allowing the processes involved in optimal foraging to be studied in the deep ocean for the first time. Arrival rates, staying times, and swimming speeds were determined for a range of scavenging fishes, allowing greatly improved estimates of scavenger abundance to be made. A key finding was that abyssal grenadiers appeared to move slowly, but continuously, with a bias towards crosscurrent movement, and often left the bait while some of it remained unconsumed (Priede et al. 1991). This finding linked to Charnov's (1976) theories on optimal foraging, which showed that animals should leave a food patch once feeding opportunity at the patch dropped below the average level for the environment as a whole. A key question was whether differences in abyssal scavenger staying time could be linked to differences in the surface productivity of the overlying waters.

Latitude and surface productivity. The great majority of primary productivity in the ocean occurs close to the surface, which, in turn, provides food to the underlying deep-water habitats. Spatial variation in surface productivity directly influences the amount of food reaching the seafloor as particulate organic matter (C. R. Smith et al. 1997), and potentially affects the amount of carrion produced by the shallow-water nekton populations. When deployed along a transect in the North Atlantic, Bathysnap revealed a fish-dominated system on the Porcupine Abyssal Plain (southwest of Ireland), with apparent fish abundance and size decreasing to the Madeira Abyssal Plain in the south (Merrett 1987). These findings and trawl data led to the theory of a zoogeographic divide at $40^{\circ} \mathrm{N}$. This theory stated that there was a lower biomass, consisting of small fish species, in the sub-tropics, where productivity was lower and more continuous, compared to in the more productive and seasonal temperate zone (Merrett 1987). When AUDOS was deployed in the abyssal Northeast Atlantic, it recorded a wide range of scavenging species, including the grenadier Coryphaenoides armatus, the eel Histiobranchus bathybius, and the ophidiids Spectrunculus grandis and Barathrites sp. (Armstrong et al. 1992). Using the AUDOS tracking data, abundance estimates were made for the Porcupine Abyssal Plain (PAP; 167 grenadiers km-2 and 180 synaphobranchid eels $\mathrm{km}^{-2}$ ) and for the Madeira Abyssal Plain (MAP; 8 grenadiers $\mathrm{km}^{-2}$ and 7 synaphobranchid eels $\mathrm{km}^{-2}$ ). As predicted by optimal foraging theory, staying times were longer at the oligo- trophic MAP. These findings supported the zoogeographic divide hypothesis, but baited camera deployments and tagging studies further south (Cape Verde Abyssal Plain, $17^{\circ} \mathrm{N}$ ) found elevated populations of grenadiers (Henriques et al. 2002). These studies showed that the lower abundances of $C$. armatus off Madeira corresponded with lower surface productivity, but that the seasonal upwelling system above the Cape Verde Abyssal Plain was capable of supporting large grenadiers. The surface productivity of an ecosystem could therefore be linked to the characteristics of its deep-water scavenging fauna.

Depth. It has long been known that community composition changes with depth, with species being found in specific depth zones (Grassle et al. 1975). Baited camera experiments confirmed trawl data showing distinct zonation in deep-sea fishes (Fig. 3). In the temperate Northeast Atlantic, baited camera data were dominated by observations of the eel Synaphobranchus kaupii on the upper slope (to around $1200 \mathrm{~m}$ ), which were then replaced by morid cods Antimora rostrata, to about $2000 \mathrm{~m}$, when they were replaced by the abyssal grenadier Coryphaenoides armatus (Armstrong et al. 1992, Priede \& Merrett 1996, Collins et al. 1999a). Collins et al. (2005) combined trawl and baited camera data to investigate patterns in the deep-sea fish community with depth. These analyses showed that, while both biomass and abundance of fishes fell with increasing depth, patterns in body size differed greatly between scavenging and non-scavenging fishes, with the scavengers (those species seen at baited cameras) increasing in average mass with depth. This was explained by a mathematical model of fish foraging, which showed that the optimum body size for fishes depended on the characteristics of the meals they utilized. Scavengers used larger but less frequent food items, and larger size provided scavengers with the endurance necessary to travel between sporadic feeding opportunities. Differences in energetic strategy between sharks and bony fishes may also explain differences in the depth distributions of osteichthyan (bony) and chondrichthyan fishes (sharks, rays, and chimaeras). To investigate this phenomenon Priede et al. (2006) collated data for 166 baited camera deployments in the Pacific, Atlantic, and Southern Oceans, and in the Mediterranean and Arabian Seas. These data showed that the entire class Chondrichthyes is confined to waters $<3000 \mathrm{~m}$ deep. All species in this class are vulnerable to the over fishing that is decimating shark populations (Myers \& Worm 2005).

At the extreme end of the depth range, baited cameras have been used in the ocean trenches, to depths in excess of $10 \mathrm{~km}$. The deepest recordings of fish were of grenadiers Coryphaenoides yaquinae at $5900 \mathrm{~m}$ 

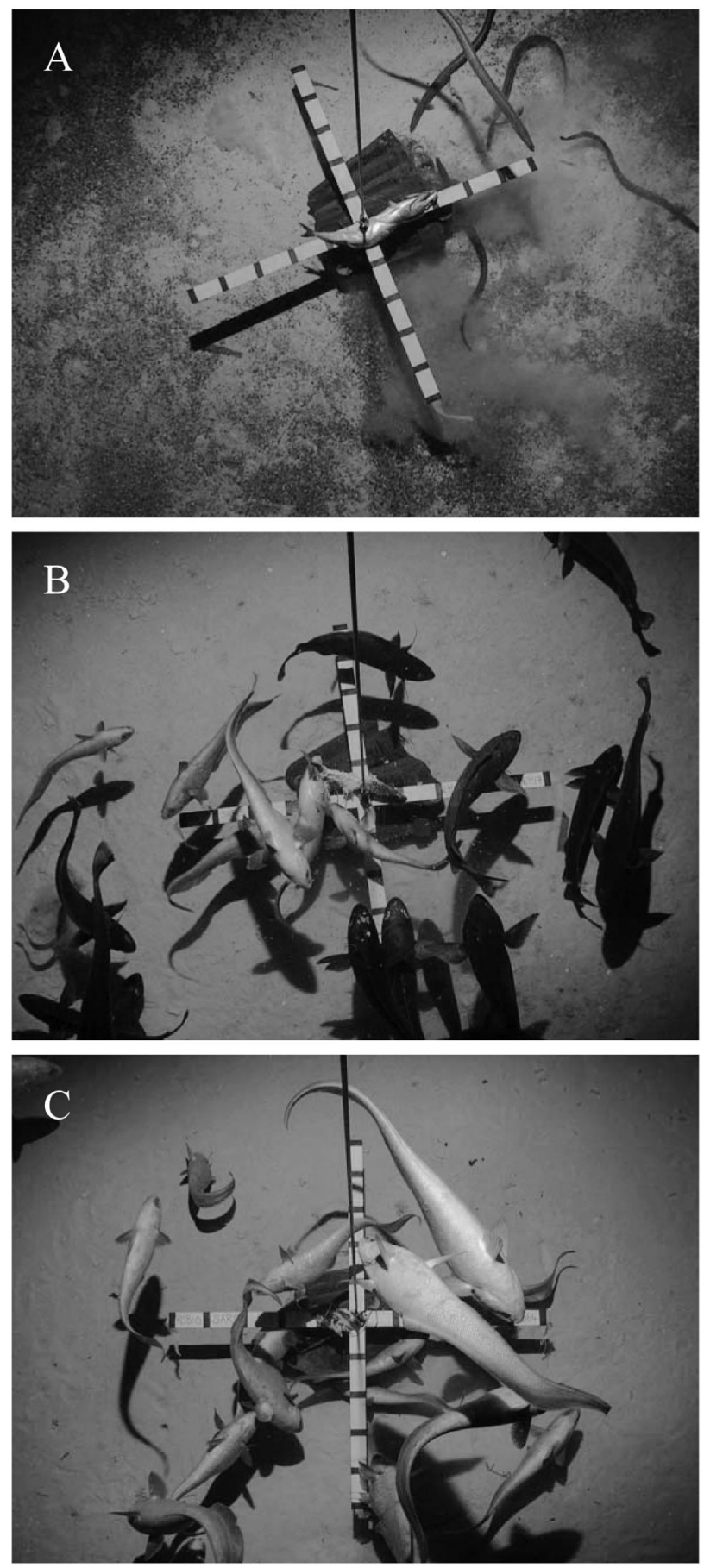

Fig. 3. Images collected by the ROBIO baited camera system on the Mid-Atlantic Ridge, July 2004. The fishes photographed are the dominant scavenging vertebrates in their respective depth zones. Reference bars are marked in $10 \mathrm{~cm}$ increments; bait is a single Atlantic mackerel. Identifications are based on morphometric measurements from the images and using specimens trawled from nearby areas: (A) eels Synaphobranchus sp. at $1569 \mathrm{~m}, 42^{\circ} 50^{\prime} \mathrm{N}, 29^{\circ} 29^{\prime} \mathrm{W}$, (B) morid Antimora rostrata (black) and grenadiers Coryphaenoides armatus (gray) at $2355 \mathrm{~m}, 53^{\circ} 17^{\prime} \mathrm{N}, 35^{\circ} 30^{\prime} \mathrm{W}$ and (C) $C$. armatus at $3346 \mathrm{~m}, 51^{\circ} 34^{\prime} \mathrm{N}, 31^{\circ} 02^{\prime} \mathrm{W}$. Note the larger size of the grenadiers in this abyssal image
(Priede et al. 1990) and brotulids at $5861 \mathrm{~m}$ (Hessler et al. 1978) in the North and South Pacific, respectively. Deeper deployments observe only scavenging crustaceans, but often in great numbers (Birstein \& Vinogradov 1955, Beliaev 1989). The true depth limits of fish distribution are not yet clear, and the mechanisms controlling the distributions of fishes are not known, as a wide range of physical (light, pressure, temperature) and ecological variables (food availability, numbers of predators) co-vary with depth. Various ecological and physiological hypotheses have been erected, but none completely explains the data (Priede et al. 2006).

Comparing abyssal basins. The majority of abyssal $(>2000 \mathrm{~m}$ ) baited camera experiments have been undertaken in the North Pacific and North Atlantic Oceans. In both of these oceans the abyssal plain fish community is dominated by large grenadiers. In the temperate Atlantic, the plains species is Coryphaenoides armatus, while in the Pacific this species is confined to the lower reaches of the ocean margins and the plains are dominated by $C$. yaquinae (Wilson \& Waples 1983). The Atlantic temperate fauna is well characterized and found consistently across a wide area, but the northern and eastern extensions of this ocean are quite different. Jones et al. (2003) described the scavenging fauna of the Mediterranean Sea, demonstrating that the large grenadiers and amphipods that dominate scavenging fauna of the oceanic abyss are absent at similar depths in this enclosed sea. The abyssal scavenging fauna is numerically dominated by a shrimp, Acanthephyra eximia (Jones et al. 2003), which can be found around hydrothermal vents in the Atlantic (Desbruyères et al. 2001). The much greater water temperatures at depth, shorter time that the Mediterranean abyss has been habitable, and the shallow sill $(<300 \mathrm{~m}$ deep), which separates this sea from the Atlantic, are all possibly responsible for preventing the entry of the 'normal' oceanic fauna. To the north, above the Arctic Circle, grenadiers are also absent, and the abyssal scavenging fauna is dominated by amphipods (Klages et al. 2001); higher up the slope the main scavenging fish are zoarcids (Premke et al. 2003). Lower temperatures in the Arctic might be a factor, but it is interesting to note that in the abyssal Arabian Sea zoarcids are also among the dominant scavenging fish species seen by baited cameras and large grenadiers are very rare (Janßen et al. 2000). Like in the Atlantic, in the southern Indian Ocean the abyssal fish community appears to be dominated by large C. armatus. (King 2006).

Temporal patterns. Spatial patterns have been extensively examined, but temporal patterns are extremely poorly characterized. Seasonal comparisons using acoustic tracking (Priede et al. 1994b) and video analysis (Priede et al. 2003) showed changing levels of 
swimming activity in abyssal fishes, but these could also have been caused by interannual changes in nutritional state (Drazen 2002). Changes in lengthfrequency distribution indicated that migrations by grenadiers may have occurred (A. Smith et al. 1997, Priede et al. 2003), but confirming this will require much more data.

\section{TECHNOLOGY FOR SURVEY AND SCIENTIFIC STUDIES}

While deployment methods differ, all systems require a camera, light, and a means of attracting animals. The choice of each item depends on the specific aims of the deployments (e.g. from survey to behavioral study) and how well characterized the fauna is prior to deployment.

Camera systems. There are many options to be considered, including the sizes and angles of the fields of view, the type of lighting, and between video and still photography. The Bathysnap and 'Eye In The Sea' (Widder et al. 2005) vehicles used oblique photography, providing a larger field of view, and good side views of the animals, making them potentially easier to identify than in top-down images. One disadvantage of this technique is that from a single camera it is impossible to estimate the sizes of animals which are not touching the seafloor (animals on the bottom can be sized using a 'Canadian grid' superimposed on the image). Oblique angled photography is mainly used for unbaited deep-sea photography, where most of the animals of interest are on the seafloor (Kaufmann \& Smith 1997, Bett et al. 2001). One other potential disadvantage of baiting an obliquely angled camera is that the results obtained may be affected if the camera's supporting structure is touching the seafloor. Jamieson et al. (2006) recently described how fish often ignore the bait and investigate lander frames, potentially making them invisible to the camera for long periods of time. For this reason, Jamieson et al. (2006) recommended that lander or mooring parts coming close to the seabed should be within the field of view of the camera.

The 'monster camera' used a downward-facing camera, tethered off the seafloor to maximize the field of view. This system was adopted in the design of the FVV (and its descendants ATEX, AUDOS, and ROBIO), using a measured scale-bar close to the seafloor. By using this reference length and calculating the range of benthopelagic animals from the position of their shadows on the seafloor, the lengths of animals can be calculated from a single camera, even when they are not in contact with the seafloor. However, the accuracy of the estimates falls dramatically as the animals get further from the seabed and the reference scale $(\mathrm{N}$. King \& D. Watson unpubl. data). With a downwardfacing camera there is clearly a trade-off between the seafloor area visible and the amount of detail available in the images, usually determined by the camera's range from the seafloor. Placing the camera closer and using a wide-angle lens is an attractive option, but causes measurement artifacts if lengths and swimming speeds are to be determined from images or video sequences.

Most baited camera deployments undertaken for survey and census reasons have used stills cameras, mainly because the increased resolution available from film made species identification easier. However, recordings of swimming movement from video can also be used when classifying organisms. Video has been used by several teams to collect information on locomotory performance and behavior in deep-sea animals. One recent example is the 'Sprint' lander, which used video in conjunction with an electrical stimulator to elicit burst swimming performances from fish and shrimps attracted to bait, allowing their muscle power output to be estimated (Bailey et al. 2003). Collins et al. (1999a) used video data, alongside acoustic tracking, to show how fish activity levels are reduced at greater depths, probably as a consequence of lower food availability.

Current high-resolution, color video cameras require relatively large amounts of light. For example, the Sprint lander used twin $75 \mathrm{~W}$ incandescent lamps (Bailey et al. 2003). Long periods of illumination at such light intensities sometimes affect the behavior of the animals that the camera is there to observe. The bathyal eel Synaphobranchus kaupii slowly moved away from the camera field of view when lit (Bailey et al. 2005), but the abyssal grenadier Coryphaenoides armatus did not avoid the lights used to illuminate it (Wilson \& Smith 1984). Recent studies suggest that $S$. kaupii interacts with bioluminescent ostracods during scavenging (Heger et al. 2007), and reacting to their light may be a natural behavior for these fishes. Other bathyal fishes, such as toothfish, also react to the lights of video landers (Collins et al. 1999b), and, like the eels, this may be because light has some ecological relevance to this species, perhaps during a shallowerliving point in their life cycle.

One solution to the lighting problem is to use a highfrequency acoustic camera, to which the fishes should be completely oblivious, but under most conditions the image quality and field of view are not as good as those of optical cameras (Rose et al. 2005). More conventional active sonars provide much greater fields of view (K. L. Smith et al. 1989), but are currently best used in conjunction with cameras (Premke et al. 2003). Camera systems using red-light illumination appear to dis- 
turb fish less than those using white light, resulting in greater numbers of scavenging animals, while providing sufficient light for video recording (Widder et al. 2005).

Baits and other attractants. After setting up all the high-tech hardware, the camera must be baited. This is a critically important part of the procedure, as small details in the size, type, and configuration of the bait affect the results obtained. The most common baits are shallow-water fishes, either in a leaky container or open to the scavengers. In either case, scavenging animals are attracted by the production of an odor plume that stretches downstream of the baited camera. This is a very cheap and effective means of attracting animals to the camera from a large area, but suffers from some significant disadvantages. The baits used are not standardized between research groups, making comparison of results difficult, as the rate of odor release and the length of time that the bait lasts depend completely on the type of fish used (Lampitt et al. 1983) and how it is prepared (homogenate, fillets, whole). The early experiments tended towards enclosed baits, but, following Priede \& Smith (1986), many teams now use open baits to mimic small natural food falls. With such open baits there is a feedback process between the numbers and sizes of the scavengers attracted and the length of time that the bait remains attractive (Collins et al. 2002). This probably makes the results obtained less consistent between deployments, and details of how the bait is attached to the camera system greatly affect how long it remains visible. Bait mixes enclosed in a mesh container or released by a pump are probably more consistent between deployments than whole fish, but the form and duration of the feeding frenzy produced cannot mimic events at a natural carrion fall. Monterey Bay Aquarium Research Institute researchers used liquidized fish, emitted by a pump, to attract mobile animals in an experiment to test the effects of deep-ocean carbon sequestration on deepliving animals (Tamburri et al. 2000). This bait was so effective that the fish remained present even when the $\mathrm{pH}$ of the water around the bait source was reduced from 7.6 to 5.6 by $\mathrm{CO}_{2}$ hydrate pumped from the ROV. While most researchers use fish in some form as bait, plant remains have also been used. Traps baited only with sea grass and seaweed captured amphipods at depths of 10 and $500 \mathrm{~m}$ off the Bahamas (Lawson et al. 1993).

Changing the type and configuration of the bait affects both the numbers of animals seen and the species observed. The Bathysnap system observed Pachycara bulbiceps, which was not observed at the same locations by Armstrong et al. (1992), but did not observe Coryphaenoides armatus, the dominant fish scavenger at that depth. Bathysnap has always used enclosed baits and tends to be deployed for longer durations than the AUDOS lander with its open bait (usually a single Atlantic mackerel Scomber scombrus). The greater persistence of the protected bait allows zoarcids to arrive and exhibit the 'roosting' behavior for which they are now well known (Witte 1999, Janßen et al. 2000, Kemp et al. 2006).

One disadvantage of small, unprotected baits is that the experiment is over very quickly (often within hours of lander touchdown), but Kemp at al. (2007) deployed a recently developed periodic bait-release system during a long-term lander experiment on the Mid-Atlantic Ridge. The periodic bait-release contained several individual fish carcasses in sealed tubes, which were released singly at pre-determined intervals. The system produced replicate baited experiments, with grenadier fishes apparently leaving the lander after feeding and being attracted when new bait was released. The sealing of the bait within the tubes and the deactivation of surface-dwelling microorganisms by the environmental pressure appeared sufficient to retain the freshness of the bait between bait releases. This system has great potential for the study of scavenging animals during periods when ship operations are impractical, such as during winter at higher latitudes.

The largest baits used on landers are the carcasses of small marine mammals (Jones 1999, Kemp et al. 2006), which attract very large numbers of scavenging fishes and invertebrates for periods of several weeks. Such studies have provided fascinating information on deep-water ecology and, in particular, on the interactions between species. For example, Kemp et al. (2006) showed that changes in numbers of crabs feeding on the carcass of a porpoise fluctuated violently, but the drops in crab numbers were associated with the presence of predatory octopods. There have been several studies of large marine mammal carcasses, made by sinking them into deep water with large weights and then visiting them periodically with ROVs and submersibles (Smith \& Baco 2003). The succession of animals at whale carcasses, began with a 'mobile scavenger' phase, similar to that seen at baited landers, ending with a 'reef' stage, when the nutritional content of the skeleton has been exhausted by sulphilophilic organisms and the bones have been colonized by suspension feeders (Smith \& Baco 2003). The observation of chemoautotrophs feeding at whale carcasses led to the 'stepping stone' theory, which suggested that whale carcasses might provide the necessary habitat to support the dispersal of vent animals from one hydrothermal fluid source to the next (C. R. Smith et al. 1989).

The above techniques attract animals by an odor plume and perhaps also by an acoustic/mechanoreceptor signal from the impact of the carcass on the 
seafloor (Klages et al. 2002, Premke et al. 2003). The only alternative artificial attractant of which the authors are aware is the 'electronic jellyfish' developed by Widder and her co-workers (Widder et al. 2005). The 'jellyfish' consists of a computer-controlled array of white LEDs, which emit moving patterns of light similar to those produced by a distressed jellyfish. It appears that this system does attract the attention of predators near the lander, but the usefulness of this system as a sole means of attracting animals to a camera has not yet been established. As noted above, scavengers may also utilize mechanoreception to detect the arrival of carrion on the seafloor, but there has been little experimental testing of this in situ.

In general terms, video cameras and open, natural baits have advantages for behavioral studies, particularly using red-light illumination. High-resolution digital stills cameras and enclosed (or at least very standardized) baits are probably better for census purposes, especially in areas where the fauna has not been characterized by previous photographic or capture methods (King et al. 2006).

Interpretation of baited camera data. Many systems exist for taking photographs and videos of the animals attracted to baited cameras, but how much information can be gleaned from the small area imaged? Baited cameras are part of a suite of techniques available to deep-sea researchers (see Table 1), but may often be the most practicable survey method. In environments such as reefs, where trawling would be unacceptably damaging, deployment of baited cameras may still be possible. Lander deployments also require less ship time and equipment than trawling, ROV, or submersible use, especially at abyssal depths. It is important then that the distribution patterns and abundance estimates produced by baited cameras are comparable to those from other methods and that any systematic differences in the results obtained should be known.

Species composition. At the simplest level, determination of species presence can be achieved relatively easily, and this work forms the basis of the comparisons between the abyssal basins presented above. It may sometimes be difficult to make good species identifications from the top-down images collected by baited camera systems (identification books seldom show a dorsal view), and careful morphometric measurements from the images may be required to discriminate anatomically similar species (King 2006). This problem was first noted by Barnes (1955), but the deep-sea implementation of the baited stereo-camera techniques used by fisheries scientists (Cappo et al. 2004) is a potential solution. Alternatively, voucher specimens for identification can be obtained by trawling (if possible) or the deployment of baited traps or hooks.
Comparisons of the species lists generated by baited camera and trawl censuses often differ greatly, as baited cameras usually only attract scavengers. In the NE Atlantic only 18 species were attracted to bait compared with 71 species taken within trawls (Priede et al. 1994a, Priede \& Merrett 1996). A recent survey of demersal fish species on the Mid-Atlantic Ridge also detected 22 species at baited landers, 40 species on a series of 1000s of baited long-line hooks, and 80 species in Campelen trawls (King et al. 2006, I. Fossen et al. unpubl. data). In a recent global comparison, more than twice as many species were found at any depth with otter trawls (OTSBs) than with baited cameras (Priede et al. 2006).

Calculating animal abundance and biomass. A more significant challenge than determining that a species is present is to estimate the true abundances of that species in the wider environment. The number of animals at the bait changes continuously during the deployment (Fig. 4), often resulting in a feeding frenzy of fish and crustaceans filling the camera field of view (Fig. 3). Interpreting these data requires information or assumptions about the sensory abilities and foraging method of the animals and about the behavior and area of influence of the odor plume after it has left the camera system.

The scenario used in the present generation of models is that the odor is carried downstream by the current and either reaches a stationary animal, or that animal swims into the odor plume while actively searching for food (Priede \& Merrett 1996, Bailey \& Priede 2002). The length and spread of the odor plume (and thus the number of animals which it contacts) are determined by the current velocity (and so a current meter is usually fitted to the lander). Upon contacting the odor, rheotaxis is triggered, and animals use the odor plume gradient to stay within the plume until they reach the baited area. They then locate the bait, feed until the bait is consumed, or leave sooner if they estimate that better feeding opportunities exist elsewhere (Charnov 1976). There are major differences between species in their tendency to remain in the vicinity of baits, and it is very difficult to determine individual staying times unless acoustic tagging is used, or a fish has an unusual distinguishing feature such as a prominent ectoparasite. The number of animals at any one time, therefore, depends on the current velocity, movement speeds of the animals (which may also be affected by current velocity), and how long the animal stays at the bait (which is determined by both its feeding rate, the actions of other animals, the bait characteristics, and the number of other feeding opportunities).

The earliest abundance calculation model was a 'sit and wait' model for crabs, developed by Sainte-Marie 

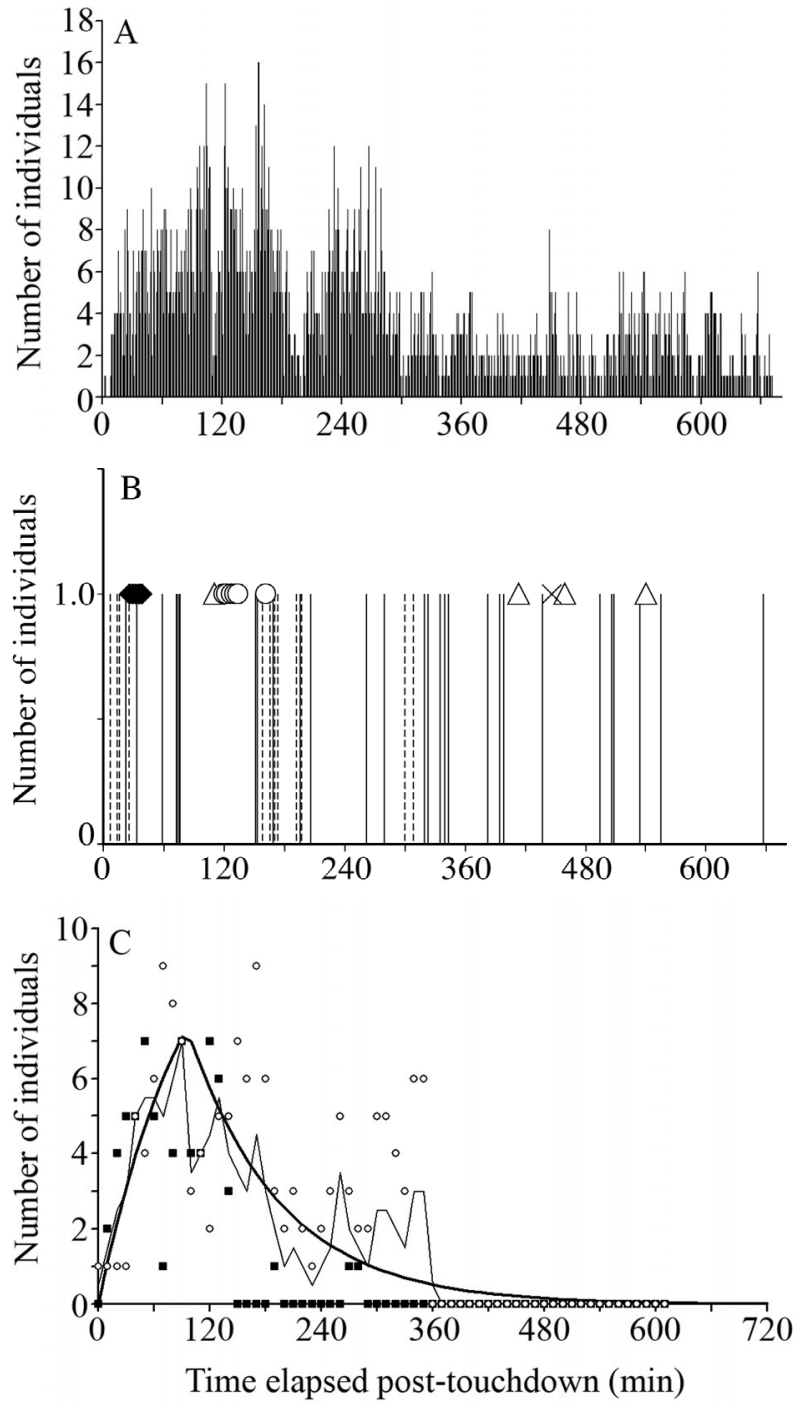

Fig. 4. (A,B) Numbers of fish within view of the camera over time after touchdown at $911 \mathrm{~m}$, Nazaré Canyon, Portuguese coast. Each vertical histogram bar represents 1 image frame with fish visible. (A) Data for Synaphobranchus spp. and (B) the other taxa recorded. Bars: the most common taxa attending bait; black bars: Mora moro; dashed bars: Trachyrincus scabrus(?). Symbols: less common visitation; crosses: Hexanchus griseus(?); open circles: Deania sp.; open triangles: unidentified sharks; filled diamonds: Phycis sp. (? = species identification uncertain). The bait was not completely consumed during the deployment. (C) Numbers of Coryphaenoides armatus as a function of time (maximum number per 10 min interval) at $3400 \mathrm{~m}$, Nazaré Canyon. Raw deployment data are represented by open circles and closed squares for each of 2 deployments. Grey line: mean number of individuals for the 2 deployments; black line: smoothed 'shark's fin' model fitted values (Priede et al. 1990)

\& Hargrave (1987), and subsequently refined by Collins et al. (2002). This latter model used the arrival rate and estimates of effective plume area to estimate abundance from the arrivals of many animals and is therefore a very robust measure. These models assume
Gaussian odor plume dispersal, that every individual of the focal species responds similarly to the odor of the bait, and that all the animals attracted remain at the bait throughout the recording. Priede et al. (1990) proposed a simple model for the calculation of fish abundances based on their first arrival time and allowing for the dispersal of fish after feeding (Fig. 4C). The model was easy to implement and produced abundance estimates which were close to those of otter trawls done at the same locations (Fig. 5A) (Priede \& Merrett 1996). This model is the basis of all the abundance estimates for AUDOS and ROBIO deployments described in this review. In an effort to develop models that described the data more accurately, Bailey \& Priede (2002) developed models that allowed for 'sit and wait', 'cross current foraging', and 'drifting' behavior patterns. Although the newer models appeared qualitatively to mimic 'real' deployment data more closely, the greatly increased difficulty of using them for abundance estimates cannot be justified on the basis of the available field data. Results from this model are shown in Fig. 5B, comparing abundance estimates from a towed camera sled to those from the Sprint video lander. Farnsworth et al. (2007, this Theme Section) criticised the use of deterministic models for abundance estimates, and presented a model which used more of the data available from arrival time patterns. Careful field trials and a statistical analysis of the model predictions will be required to determine which models are the most appropriate for the analysis of baited camera data.

Once abundances have been estimated, scavenger biomass can be calculated, using animal dimensions and allometric relationships. In comparison with trawl data in the NE Atlantic, landers sampled a more limited size range, not fully representing juveniles and very large specimens of Coryphaenoides armatus. Noting this difference in size frequency led to the discovery that brain morphology changes throughout life in C. armatus as its niche changes ontogenetically (Wagner 2003).

Data gaps. There are significant gaps in our understanding of both odor plume and animal foraging behavior. For instance, we know little about the odor sensitivity of deep-sea animals, or how the odor plume disperses, especially in rough terrain such as reefs and canyons (Fig. 5C). While the AUDOS tracking system has provided much useful behavioral information, these data could only be collected after the animal had fed (and eaten the transponder) and therefore could not describe the animals' previous actions (e.g. its reaction to the plume). At this time we lack critical information on energetic strategies, such as which animals remain stationary on the seafloor until contacted by an odor plume (Wilson \& Smith's [1984] 'sit and 


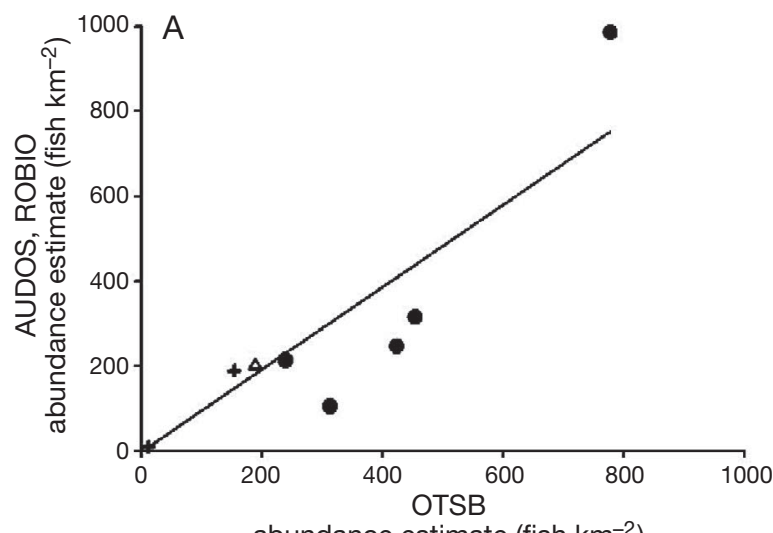

abundance estimate (fish $\mathrm{km}^{-2}$ )

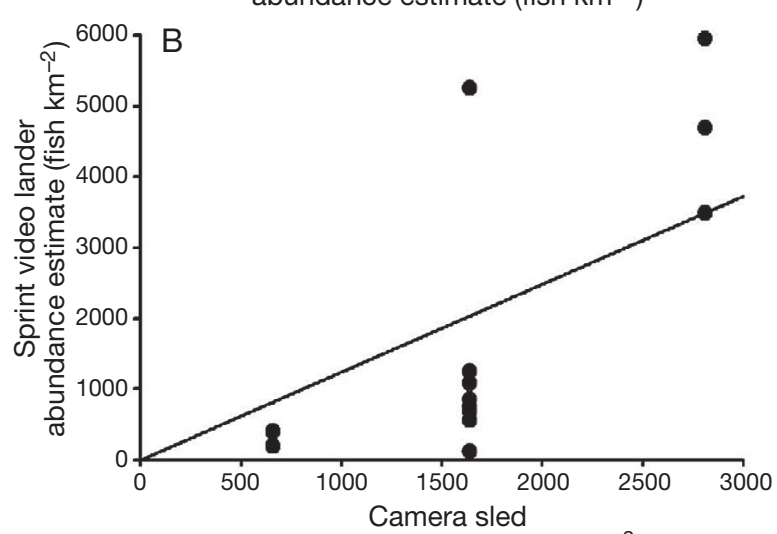

abundance estimate (fish $\mathrm{km}^{-2}$ )

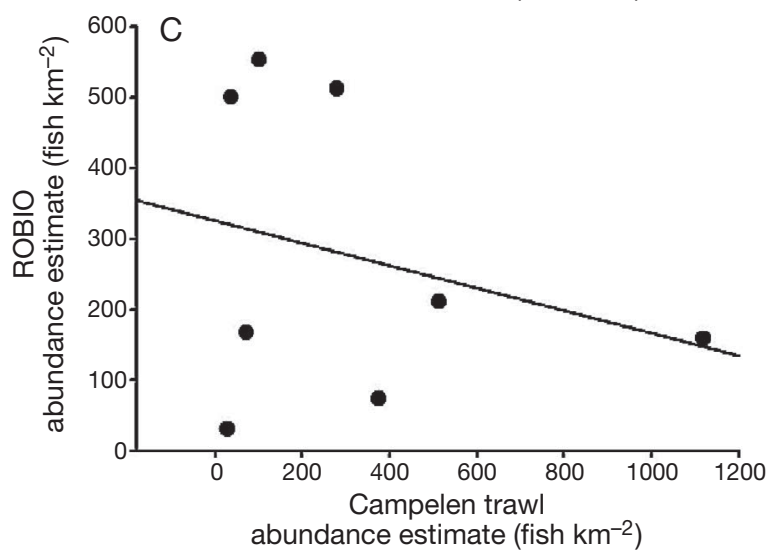

Fig. 5. Comparison of abundance estimates from towed gears and baited cameras, obtained at the same locations and during the same weeks. Lines are least squares regression fits; Spearman correlations were used to determine the strength of the relationships. (A) Otter trawls (OTSB) in the Porcupine Seabight $(\bullet)$, Porcupine Abyssal Plain (averages of several trawls, +) and Crozet Island $(\Delta)$; plotted against AUDOS/ROBIO data $(y=0.97 x$, correlation coefficient $=$ $0.86, \mathrm{p}=0.01, \mathrm{n}=8$ ). (B) Camera sled data from the North Pacific, plotted against Sprint video lander abundances estimates $(y=1.24 x$, correlation coefficient $=0.62, \mathrm{p}=0.02, \mathrm{n}=$ 14). (C) Campelen trawls on the Mid-Atlantic Ridge, plotted against ROBIO data $(y=-0.15 x$, correlation coefficient $=$ $0.02, p=0.96, n=8)$. Note that in $(A)$ and $(C)$ the variation in abundance is due to spatial separation, whereas in (B) the lander and camera sled estimates are all for the same location, but the pairs were collected over a period of $15 \mathrm{yr}$ wait' strategy) and which animals search across currents as other authors have suggested (Barnes 1955, Priede et al. 1991). Basic sensitivity analyses have shown how abundance estimates are greatly affected by assumptions concerning an animal's foraging method (Bailey \& Priede 2002) and swimming speed (Yau et al. 2000), so some of these data gaps will need to be filled if we are to have confidence in lander abundance estimates.

\section{SUMMARY}

Baited cameras gave us our first view of a diverse, abundant, and active scavenging fauna in the dark ocean abyss, and, in many cases, deploying baited cameras is still one of the most effective ways of obtaining biological information from deep water. Worldwide surveys have shown patterns in scavenger behavior, abundance, and diversity with latitude, depth, and between oceans. Despite long experience in the use of these camera systems, many data gaps remain, which make interpreting the images obtained more difficult. The choice of camera system and bait and the amount of background information available about the environment and the focal species make a great deal of difference to the success of the data interpretation. All survey techniques have assumptions. The avoidance and attraction effects of moving survey gears such as trawls, camera sleds, and ROVs are poorly known for deep-sea animals, affecting their effective search area in much the same way that errors are caused in baited camera surveys (Trenkel et al. 2004). Baited cameras have a long history, and, with care, their deployment provides an efficient means of studying the distribution, behavior, and abundance of deep-sea animals.

Acknowledgements. D.M.B. and the Pacific data collection were supported by a Marie Curie Outgoing International Fellowship (MCOIF-CT-2004-509286). N.J.K. was supported by NERC Grant NER/S/A/2003/11190 and a Johnstone and Florence Stoney Studentship from the BFWG. The Mid-Atlantic Ridge, Crozet Plateau, and Nazaré Canyon experiments were supported by the Census of Marine Life, Mid-Atlantic Ridge Ecosystem, Crozet Benthic (D300), and Hotspot Ecosystem Research on the Margin of the European Seas (D297) programs as part of N.J.K.'s PhD research. The technical and financial support of Ken Smith and his team at Scripps Institution of Oceanography, and Oceanlab, University of Aberdeen, are gratefully acknowledged.

\section{LITERATURE CITED}

Armstrong JD, Bagley PM, Priede IG (1992) Photographic and acoustic tracking observations of the behaviour of the grenadier Coryphaenoides (Nematonurus) armatus, the eel 
Synaphobranchus bathybius, and other abyssal demersal fish in the North Atlantic Ocean. Mar Biol 112:535-544

Bagley P, Smith A, Priede IG (1994) Tracking movements of deep demersal fishes in the Porcupine Seabight, Northeast Atlantic Ocean. J Mar Biol Assoc UK 74:473-480

Bagley PM, Priede IG, Jamieson AJ, Bailey DM, Battle EJV, Henriques C, Kemp KM (2004) Lander techniques for deep ocean biological research. Underw Technol 26:3-12

Bailey DM, Priede IG (2002) Predicting fish behaviour in response to abyssal food-falls. Mar Biol 141:831-840

Bailey DM, Bagley PM, Jamieson AJ, Collins MA, Priede IG (2003) In situ investigation of burst swimming and muscle performance in the deep-sea fish Antimora rostrata. J Exp Mar Biol Ecol 286(6):295-311

Bailey DM, Genard B, Collins MA, Rees JF and others (2005) High swimming and metabolic activity in the deep-sea eel Synaphobranchus kaupii revealed by integrated in situ and in vitro measurements. Physiol Biochem Zool 78:335-346

Barnes H (1955) Underwater television and research in marine biology, bottom topography and geology. Ocean Dyn 8: 213-236

Beliaev GM (1989) Deep-sea ocean trenches and their fauna. Nauka Publishing House, Moscow

Bett BJ (2003) Time-lapse photography in the deep sea. Underw Technol 25:121-127

Bett BJ, Malzone MG, Narayanaswamy BE, Wigham BD (2001) Temporal variability in phytodetritus and megabenthic activity at the seabed in the deep Northeast Atlantic. Prog Oceanogr 50:349-368

Birstein YA, Vinogradov ME (1955) Pelagicheskie gammaridy severnoi chasti Indiiskogo Okeana [The pelagic amphipods gammarids of the northern part of the Indian Ocean]. Tr Inst Okeanol Akad Nauk SSSR 65:152-195 (in Russian)

Cappo M, Speare P, De'ath G (2004) Comparison of baited remote underwater video stations (BRUVS) and prawn (shrimp) trawls for assessments of fish biodiversity in interreefal areas of the Great Barrier Reef Marine Park. J Exp Mar Biol Ecol 302:123-152

Charnov EL (1976) Optimal foraging, the marginal value theorem. Theor Popul Biol 9:129-136

Collins MA, Priede IG, Bagley PM (1999a) In situ comparison of activity in two deep-sea scavenging fishes occupying different depth zones. Proc R Soc Lond B 266:2011-2016

Collins MA, Yau C, Nolan CP, Bagley PM, Priede IG (1999b) Behavioural observations on the scavenging fauna of the Patagonian slope. J Mar Biol Assoc UK 79:963-970

Collins MA, Yau C, Guillfoyle F, Bagley P, Everson I, Priede IG, Agnew D (2002) Assessment of stone crab (Lithodidae) density on the South Georgia slope using baited video cameras. ICES J Mar Sci 59:370-379

Collins MA, Bailey DM, Ruxton GD, Priede IG (2005) Trends in body size across an environmental gradient: a differential response in scavenging and non-scavenging demersal deep-sea fish. Proc R Soc Lond B 272:2051-2057

Dayton PK, Hessler RR (1972) Role of biological disturbance in maintaining diversity in the deep sea. Deep-Sea Res 19: 199-208

Desbruyères D, Biscoito $M$, Caprais $\mathrm{JC}$, Colaço $\mathrm{A}$ and others (2001) Variations in deep-sea hydrothermal vent communities on the Mid-Atlantic Ridge near the Azores plateau. Deep-Sea Res I 48:1325-1346

Drazen JC (2002) A seasonal analysis of the nutritional condition of deep-sea macrourid fishes in the North-East Pacific. J Fish Biol 60:1280-1295

Ewing M, Worzel JL, Vine AC (1967) Early development of ocean-bottom photography at Woods Hole Oceanographic Institution and Lamont Geological Observatory. In: Hersey
JB (ed) Deep-sea photography. Johns Hopkins Press, Baltimore, MD, p 13-41

Farnsworth KD, Thygesen UH, Ditlevsen S, King NJ (2007) How to estimate scavenger fish abundance using baited camera data. Mar Ecol Prog Ser 350:223-234

Fossen I, Cotton CF, Bergstad OA, Dyb JE (2007) Species composition and distribution patterns of fishes captured by longlines on the Mid-Atlantic Ridge. Deep-Sea Res II (in press)

Grassle JF, Sanders HL (1973) Life histories and the role of disturbance. Deep-Sea Res 20:643-659

Grassle JFH, Sanders HL, Hessler RR, Rowe GT, McLellan T (1975) Pattern and zonation - a study of bathyal megafauna using the research submersible Alvin. Deep-Sea Res 22: $457-481$

Heezen BC, Hollister CD (1971) The face of the deep. Oxford University Press

Heger A, King NJ, Wigham BD, Jamieson AJ and others (2007) Benthic bioluminescence in the bathyal North East Atlantic: luminescent responses of Vargula norvegica (Ostracoda: Myodocopida) to predation by the deep water eel (Synaphobranchus kaupii). Mar Biol 151:1471-1478. doi: 10.1007/s00227-006-0587-7

Henriques C, Priede IG, Bagley PM (2002) Baited camera observations of deep-sea demersal fishes of the Northeast Atlantic Ocean at $15-28^{\circ} \mathrm{N}$ off West Africa. Mar Biol 141:307-314

Hessler RR, Ingram CL, Yayanos AA, Burnett BR (1978) Scavenging amphipods from the floor of the Philippine trench. Deep-Sea Res 25:1029-1047

Isaacs JD (1969) The nature of oceanic life. Sci Am 211:146-162 Isaacs JD, Schwartzlose RA (1975) Active animals of the deepsea floor. Sci Am 233:85-91

Jamieson AJ (2004) Autonomous lander technology for biological research at mid-water, abyssal and hadal depths. PhD thesis, University of Aberdeen

Jamieson AJ, Bailey DM, Wagner HJ, Bagley PM, Priede IG (2006) Behavioural responses to structures on the seafloor by the deep-sea fish Coryphaenoides armatus: implications for the use of baited landers. Deep-Sea Res I 53:1157-1166

Janßen F, Treude T, Witte U (2000) Scavenger assemblages under different trophic conditions: a case study in the deep Arabian Sea. Deep-Sea Res II 47:2999-3026

Jones EG (1999) 'Burial at sea': consumption and dispersal of large fish and cetacean food-falls by deep-sea scavengers in the Northeast Atlantic Ocean and eastern Mediterranean Sea. PhD thesis, University of Aberdeen

Jones EG, Collins MA, Bagley PM, Addison S, Priede IG (1998) The fate of cetacean carcasses in the deep-sea: observations on consumption rates and succession of scavenging species in the abyssal North-East Atlantic. Proc R Soc Lond B 265: $1119-1127$

Jones EG, Tselepides A, Bagley PM, Collins MA, Priede IG (2003) Bathymetric distribution of some benthic and benthopelagic species attracted to baited cameras and traps in the eastern Mediterranean. Mar Ecol Prog Ser 251:75-86

Kaufmann RS, Smith KL (1997) Activity patterns of mobile epibenthic megafauna at an abyssal site in the eastern North Pacific: results from a 17-month time-lapse photographic study. Deep-Sea Res I 44:559-579

Kemp KM, Jamieson AJ, Bagley PM, McGrath H, Bailey DM, Collins MA, Priede IG (2006) Consumption of a large bathyal food fall, a six month study in the North-East Atlantic. Mar Ecol Prog Ser 310:65-76

Kemp KM, Jamieson AJ, Bagley PM, Collins MA, Priede IG (2007) A new technique for sequential periodic bait-release at a camera platform in the deep sea; trial at $3664 \mathrm{~m}$ depth in the Charlie Gibbs Fracture Zone, Mid-Atlantic Ridge. Deep-Sea Res I (in press) 
King NJ (2006) Deep-sea demersal ichthyofauna of contrasting localities: Mid-Atlantic Ridge, Nazaré Canyon (North Atlantic Ocean) and Crozet Plateau (southern Indian Ocean), with special reference to the abyssal grenadier, Coryphaenoides (Nematonurus) armatus (Hector, 1875). $\mathrm{PhD}$ thesis, University of Aberdeen

King NJ, Bagley PM, Priede IG (2006) Depth zonation and latitudinal distribution of deep-sea scavenging demersal fishes of the Mid-Atlantic Ridge, 42 to $53^{\circ}$ N. Mar Ecol Prog Ser 319:263-274

Klages M, Vopel K, Bluhm H, Brey T, Soltwedel T, Arntz WE (2001) Deep-sea food falls: first observation of a natural event in the Arctic Ocean. Polar Biol 24:292-295

Klages M, Muyakshin S, Soltwedel T, Arntz WE (2002) Mechanoreception, a possible mechanism for food fall detection in deep-sea scavengers. Deep-Sea Res I 49:143-155

Lampitt RS, Burnham MP (1983) A free-fall time-lapse camera and current-meter system bathysnap with notes on the foraging behavior of a bathyal decapod shrimp. Deep-Sea Res I 30:1009-1017

Lampitt RS, Merrett N, Thurston MN (1983) Inter-relations of necrophagus amphipods, a fish predator and tidal currents in the open sea. Mar Biol 74:73-78

Laver MB, Olsson MS, Endelman JL, Smith KL (1985) Swimming rates of scavenging deep-sea amphipods recorded with a free-vehicle video camera. Deep-Sea Res I 32:1135-1142

Lawson GS, Tyler PA, Young CM (1993) Attraction of deep-sea amphipods to macrophyte food falls. J Exp Mar Biol Ecol 169:33-39

Merrett NR (1987) A zone of faunal change in assemblages of abyssal demersal fish in the eastern North Atlantic: A response to seasonality in production? Biol Oceanogr 5:137-151

Myers RA, Worm B (2005) Extinction, survival or recovery of large predatory fishes. Philos Trans R Soc Lond B 360:13-20

Premke K, Muyakshin S, Klages M, Wegner J (2003) Evidence for long-range chemoreceptive tracking of food odour in deep-sea scavengers by scanning sonar data. J Exp Mar Biol Ecol 285/286:283-294

Priede IG, Bagley PM (2000) In situ studies on deep-sea demersal fishes using autonomous unmanned lander platforms. Oceanogr Mar Biol Annu Rev 38:357-392

Priede IG, Merrett NR (1996) Estimation of abundance of abyssal demersal fishes: a comparison of data from trawls and baited cameras. J Fish Biol 49:207-216

Priede IG, Smith KL (1986) Behaviour of the abyssal grenadier Coryphanoides yaquinae, monitored using ingestible acoustic transmitters in the Pacific Ocean. J Fish Biol 29:199-206

Priede IG, Smith KL, Armstrong JD (1990) Foraging behaviour of abyssal grenadier fish: inferences from acoustic tagging and tracking in the North Pacific Ocean. Deep-Sea Res 37:81-101

Priede IG, Bagley PM, Armstrong JD, Smith KL, Merrett NR (1991) Direct measurement of active dispersal of food-falls by deep-sea demersal fishes. Nature 351:647-649

Priede IG, Bagley PM, Smith A, Creasey S, Merrett NR (1994a) Scavenging deep demersal fishes of the Porcupine Seabight, North-east Atlantic: observations by baited camera, trap and trawl. J Mar Biol Assoc UK 74:481-498

Priede IG, Bagley PM, Smith KL (1994b) Seasonal change in activity of abyssal demersal scavenging grenadiers Coryphaenoides (Nematonurus) armatus in the eastern Pacific Ocean. Limnol Oceanogr 39:279-285

Priede IG, Deary AR, Bailey DM, Smith KL (2003) Low activity and seasonal change in population size structure of grenadiers in the oligotrophic abyssal Central North Pacific Ocean. J Fish Biol 63:187-196

Priede IG, Froese R, Bailey DM, Bergstad OA and others (2006) The absence of sharks from abyssal regions of the world's

Editorial responsibility: Howard Browman (Associate Editorin-Chief), Storebø, Norway oceans. Proc R Soc Lond B 273:1435-1441

Rose CS, Stoner AW, Matteson K (2005) Use of high-frequency imaging sonar to observe fish behaviour near baited fishing gears. Fish Res 76:291-304

Sainte-Marie B, Hargrave BT (1987) Estimation of scavenger abundance and distance of attraction to bait. Mar Biol 94:431-443

Seibel BA, Drazen JC (2007) The rate of metabolism in marine animals: environmental constraints, ecological demands and energetic opportunities. Philos Trans R Soc Lond B 362:2061-2078

Smith A, Priede IG, Bagley PM, Addison SW (1997) Interception and dispersal of artificial foodfalls by scavenging fishes in the abyssal Northeast Atlantic: early-season observations prior to annual deposition of phytodetritus. Mar Biol 128: $329-336$

Smith CR (1985) Food for the deep sea: utilization, dispersal and flux of nekton falls at the Santa Catalina Basin floor. Deep-Sea Res 32:417-442

Smith CR, Baco AR (2003) Ecology of whale falls at the deepsea floor. Oceanogr Mar Biol Annu Rev 41:311-354

Smith CR, Kukert H, Wheatcroft RA, Jumars PA (1989) Vent fauna on whale remains. Nature 341:27-28

Smith CR, Berelson W, Demaster DJ, Dobbs FC and others (1997) Latitudinal variations in benthic processes in the abyssal equatorial Pacific: control by biogenic particle flux. Deep-Sea Res II 44:2295-2317

Smith KL, Alexandrou D, Edelman JR (1989) Acoustic detection and tracking of abyssopelagic animals: description of an autonomous split-beam acoustic array. Deep-Sea Res 36:1427-1441

Stockton WL, DeLaca TE (1982) Food falls in the deep-sea: occurrence, quality and significance. Deep-Sea Res 29:157-169

Tamburri MN, Peltzer ET, Freiderich GE, Aya I, Yamane K, Brewer PG (2000) A field study of the effects of $\mathrm{CO}_{2}$ ocean disposal on mobile deep-sea animals. Mar Chem 72:95-101

Thurston $\mathrm{MH}$, Bett BJ, Rice AL (1995) Abyssal megafaunal necrophages: latitudinal differences in the eastern North Atlantic. Int Rev Gesamten Hydrobiol 80:267-286

Trenkel VM, Lorance P, Mahévas S (2004) Do visual transects provide true population density estimates for deepwater fish? ICES J Mar Sci 61:1050-1056

Wagner HJ (2003) Volumetric analysis of brain areas indicates a shift in sensory orientation during development in the deep-sea grenadier Coryphaenoides armatus. Mar Biol 142: 791-797

Widder EA, Robison BH, Reisenbichler KR, Haddock SHD (2005) Using red light for in situ observations of deep-sea fishes. Deep-Sea Res I 52:2077-2085

Wilson RR, Smith KL (1984) Effect of near-bottom currents on detection of bait by the abyssal grenadier fishes Coryphaenoides spp., recorded in situ with a video camera on a free fall vehicle. Mar Biol 84:83-91

Wilson RR, Waples RS (1983) Distribution, morphology, and biochemical genetics of Coryphaenoides armatus and Coryphaenoides yaquinae (Pisces, Macrouridae) in the central and eastern North Pacific. Deep-Sea Res 30:1127-1145

Witte U (1999) Consumption of large carcasses by scavenger assemblages in the deep Arabian Sea: observations by baited camera. Mar Ecol Prog Ser 183:139-147

Yau C, Priede IG, Collins MA (2000) Estimation of the abundance of deep-sea fishes: telemetry and the problem of measuring swimming speed. In: Moore A, Russell I (eds) Advances in fish telemetry. Proceedings of the 3rd conference on fish telemetry in Europe (Norwich, June 1999). Ministry of Agriculture, Fisheries and Food, Lowestoft, p 159-164 